Dr DRAGAN NOVAKOVIĆ, naučni savetnik

Kancelarija Vlade Srbije za saradnju sa crkvama

i verskim zajednicama

Novi Beograd

UDK 271.222(497.11)-725-735:34(497.1)"1918/1931"

Bulevar Mihajla Pupina 2

322:271.222(497.11)-735(497.1)"1918/1931"

\title{
REŠAVANJE MATERIJALNOG POLOŽAJA SVEŠTENIKA SRPSKE PRAVOSLAVNE CRKVE U KRALJEVINI SHS/JUGOSLAVIJI DO USVAJANJA CRKVENOG USTAVA 1931. GODINE
}

\begin{abstract}
APSTRAKT: Članak se bavi složenim i važnim pitanjem rešavanja materijalnog položaja sveštenstva Srpske pravoslavne crkve u novoj državi. Polazeći od velikih žrtava podnetih tokom rata i zasluga za ostvarivanja ciljeva srpskog rukovodstva, episkopat i sveštenstvo jednoglasno su istupili sa zahtevom da se taj problem rešava donošenjem odgovarajućeg zakona. Podneto je više tekstova, ali do njihovog usvajanja nije došlo zbog političkog stava o neophodnosti poštovanja ranije postignutih dogovora $i$ ustavnih rešenja o ravnopravnosti priznatih $i$ usvojenih konfesija. Uvažavajući težak materijalni položaj sveštenstva i ne odstupajući od opredeljenja da donete norme važe za sve, usvojena je uredba o dodacima na skupoću, koja je svim sveštenicima i verskim službenicima obezbedila osnovnu socijalnu sigurnost. Precizno utvraujući nagrade pravoslavnim sveštenicima za izvršene verske obrede, država je novom uredbom poslala jasnu poruku da ne namerava da se odrekne kontrole nad Srpskom pravoslavnom crkvom i da će primenjivati norme i postupke koji nisu predviđeni za druge konfesije.
\end{abstract}

Ključne reči: Srpska pravoslavna crkva, materijalni položaj, sveštenstvo, Kraljevina, zakon, uredba

Proglašenjem Kraljevine SHS i definisanjem granica u okviru više međunarodnih ugovora, svih šest pokrajinskih crkava koje su okupljale srpski narod našle su se u teritorijalnom okviru nove države. Ranije razrađivana strategija o ujedinjenju i obnovi Pećke patrijaršije odmah je aktivirana, tako da je na inicijativu Kraljevske vlade 18. decembra 1918. sazvana Prva konferencija svih episkopa oblasnih crkava u Sremskim Karlovcima. Učesnici konferencije bili su jednoglasni u stavu da je potrebno izvršiti ujedinjenje, 
ali u skladu sa kanonima i vekovnim običajima koji vladaju u pravoslavnoj crkvi. Razmotren je i prihvaćen stav mitropolita iz Bosne i Hercegovine koji su 1. decembra 1918. odlučili o sjedinjavanju tamošnjih eparhija sa Beogradskom mitropolijom i primljena je odluka Svetog arhijerejskog sinoda Karlovačke mitropolije od 16. decembra 1918. o ujedinjenju i ponovnom uspostavljanju Srpske patrijaršije i vraćanju u kanonski poredak dve istorijske eparhije iz sastava Bukovinsko-dalmatinske mitropolije.

Donošenjem pozitivne odluke Svetog arhijerejskog sabora Crkve $u$ Srbiji 27. februara 1919. o ujedinjenju i davanjem saglasnosti Crkve u Crnoj Gori na odluke iz Sremskih Karlovaca, stekli su se uslovi i zakazana je Druga konferencija episkopa pokrajinskih crkava u Beogradu 24. maja 1919. Utvrdivši jednoglasnu volju pokrajinskih crkava, konferencija je 26. maja donela odluku kojom je utvrđeno duhovno, moralno i administrativno jedinstvo Crkve u svim srpskim oblastima. Radi uspešnijeg rešavanja mnogobrojnih i složenih poslova oko ujedinjenja izabrano je uže operativno telo kao izvršni organ konferencije pod nazivom Središnji arhijerejski sabor Ujedinjene Srpske crkve u koji su uključena četiri arhijereja na čelu sa mitropolitom crnogorsko-primorskim.

Mešovita crkveno-državna delegacija otpočela je pregovore sa bukovinskim mitropolitom radi otpusta dalmatinsko-istarske i boko-kotorske mitropolije i sa Vaseljenskom patrijaršijom za uključivanje mitropolija $u$ Bosni i Hercegovini, Makedoniji i na Kosovu i Metohiji u sastav ujedinjene Srpske pravoslavne crkve. Posle uspešno završenih razgovora dobijen je otpusni list za primorske eparhije, što je omogućilo Svetom arhijerejskom sinodu Karlovačke mitropolije da 20. decembra 1919. donese odluku o kanonskom prijemu u svoj sastav. Kraljevska vlada je vodila pregovore sa Svetim arhijerejskim sinodom Vaseljenske patrijaršije, koji su 18. marta 1920. uspešno okončani. Saglasno sporazumu, Sveti arhijerejski sinod Vaseljenske patrijaršije doneo je 19. marta 1920. odluku o priznavanju Svete autokefalne ujedinjene pravoslavne Srpske Crkve. Uvažavajući rezultate pregovora, prestolonaslednik Aleksandar je u ime kralja Petra I posebnim ukazom od 17. juna 1920. proglasio ujedinjenje svih pravoslavnih oblasti u Kraljevstvu Srba, Hrvata i Slovenaca u jednu Autokefalnu ujedinjenu srpsku pravoslavnu crkvu.

Uspešno obavivši sve planirane poslove, ponovo sazvana konferencija proglasila se Svetim arhijerejskim saborom, koji je 30. avgusta 1920. u Sremskim Karlovcima doneo Odluku o podizanju Autokefalne ujedinjene pravoslavne Srpske crkve na stupanj Patrijaršije. Svečanom činu prisustvovali su regent Aleksandar, predsednici Vlade i Narodne skupštine i druge visoke zvanice. Tokom svečanosti ministar vera pročitao je ukaz kralja Petra I kojim je potvrđena odluka Svetog arhijerejskog sabora o usposta- 
vljanju Patrijaršije i određena titula vrhovnom poglavaru „Srpski patrijarh Pravoslavne Crkve u Kraljevini SHS“. Navedenim odlukama i izborom srpskog mitropolita Dimitrija za patrijarha završeno je uspostavljanje jedinstva Crkve na celokupnom državnom prostoru.

\section{Materijalni položaj i nastojanje da se uredi zakonom}

Stvaranje Kraljevine SHS i ujedinjenje svih pokrajinskih crkava u Patrijaršiju episkopat, sveštenstvo i monaštvo dočekali su bez trećine kadra, jer je od ukupno 2.565 sveštenika na različite načine stradalo $863 .{ }^{1}$ Osiromašeni narod u razorenoj državi celokupnu energiju usmerio je na rešavanje egzistencijalnih pitanja, tako da nije bio u mogućnosti da ispunjava zakonske i običajima preuzete obaveze prema sveštenstvu. Sporo rešavanje verskog pitanja i nedostatak političke volje za efikasno donošenje potrebnih zakona direktno su doprineli da i nova država nastavi sa primenom nasleđenih propisa kojima je uređivan materijalni položaj sveštenstva. Zakon o uređenju svešteničkog stanja od 31. decembra 1882. primenjivan je na teritoriji Kraljevine Srbije i u krajevima oslobođenim Balkanskim ratovima. Sveštenici u Crnoj Gori bili su izjednačeni sa činovnicima i primali su državnu platu na osnovu Zakona o parohijskom sveštenstvu od 15. januara 1909. ${ }^{2}$ Materijalni položaj sveštenika u Karlovačkoj mitropoliji

${ }^{1}$ Prema jednoj pouzdanoj analizi tokom Prvog svetskog rata jedan episkop je spaljen, a drugi umro u internaciji. Neprijatelj je pobio ili je u internaciji stradalo 242 sveštenika, dok je 11 umrlo u borbenim dejstvima. Austro-Ugarska je internirala jednog mitropolita i 189 sveštenika, a Bugarska jednog mitropolita, dva episkopa i 230 sveštenika. Iz krajeva koji su pripadali Austro-Ugarskoj internirano je 185 sveštenika. Videti: Zakonski projekt o privremenom uređenju materijalnog stanja pravoslavnog parohijskog sveštenstva, Vesnik Srpske crkve, avgust 1922, 6.

${ }^{2}$ Prema odredbama tog zakona, osnovna plata parohijskog sveštenstva iznosila je 960 perpera. Svake pete godine sticalo se pravo na povišicu od 240 perpera iz čega je proizlazilo da sveštenik sa 30 godina službe ima primanja od 2.400 perpera. Sveštenici na Cetinju imali su pravo na poseban godišnji dodatak od 720 perpera, u Podgorici i Nikšiću 600, a u ostalim oblasnim mestima po 480 perpera. Navedena primanja isplaćivana su iz državne kase. Redovna plata obavezivala je sveštenike da sledeće verske obrede obavljaju potpuno besplatno: služba u crkvi nedeljom i praznikom; opšta molebstvija naređena od viših crkvenih vlasti; litija u svakoj parohiji jednom godišnje; osvećivanje bogojavljenske vode; propovedanje o većim praznicima; obavljanje znamenja i vodice pri rođenju deteta u kući; krštenja u crkvi; prekada u kući svakog parohijana; oglašavanje nedeljom i praznikom za one koji stupaju u brak; opelo nad umrlim i sprovod do groblja; godišnji opšti parastos; poseban parastos na Spasovdan i Vidovdan poginulim za otadžbinu; prizivanje Svetog Duha na početku školske godine i blagodarenje na završetku; posebna blagodarenja povodom državnih svetkovina i kad narede crkvene vlasti; osvećivanje vodicu u svim školama na dan Sv. Save; ispovedanje zdravih u crkvi, a bolesnih u domu; zaklinjanje opštinskih i državnih službenika; sprečavanje inoveraca da vređaju pravoslavnu crkvu; vođenje svih matičnih knjiga, izdavanje izvoda iz registara; popunjavanje obrazaca za državnu statistiku; mirenje zavađenih supruga 
rešavan je na osnovu odredaba Kraljevskog reskripta od 10. avgusta 1868. prema kome su bile određene plate od 800 do 2.000 kruna u zavisnosti od veličine parohija podeljenih na šest razreda. ${ }^{3}$ Uredba crkveno-prosvetne uprave srpskih pravoslavnih eparhija u Bosni i Hercegovini iz 1905. godine utvrdila je stalne plate sveštenstvu koje su isplaćivali autonomni crkveni organi. ${ }^{4}$ Zakonom od 19. septembra 1898. pravoslavni sveštenici u Dalmaciji dobijali su nagradu za obavljene verske poslove od naroda, a država je bila dužna da uplaćuje razliku ukoliko se ne prikupi kongrua, odnosno najniže predviđeni prihod.

Uvažavajući iskazani patriotizam i podnete žrtve Srpske crkve, kao i nezavidan materijalni položaj sveštenstva, prvi ministar vera dr Tugomir Alaupović obrazovao je 20. juna 1919. uz Središnji arhijerejski sabor anketu sa zadatkom da unifikuje zakonodavstvo i pripremi zakon o svešteničkim platama. Postupajući po nalogu, izrađen je Projekat zakona o platama i penzijama pravoslavnih parohijskih sveštenika, čija su rešenja u velikoj meri bila identična sa „Predlogom zakona o uređenju svešteničkog stanja“ Svetog arhijerejskog sabora i Vlade Kraljevine Srbije iz februara $1905 .^{5}$ Prilikom izrade navedenog projekta korišćena su i određene odredbe crnogorskog Zakona o parohijskom sveštenstvu iz 1909. godine. Razmatrajući ponuđeni projekat, udruženo pravoslavno sveštenstvo, na vanrednoj skupštini održanoj od 20. do 22. avgusta 1919, usvojilo je rezoluciju u kojoj je zatraženo hitno donošenje zakona o svešteničkim platama i dato više konkretnih primedaba koje je trebalo ugraditi u konačnu verziju. Središnji ahrijerejski sabor dostavio je Projekat zakona Trećoj konferenciji arhijereja Ujedinjene srpske pravoslavne crkve održanoj decembra 1919, koja je izvršila manje izmene, usvojila pod nazivom Nacrt zakona o izdržavanju pravoslavnog parohijskog sveštenstva i prosledila ministru vera. ${ }^{6}$ Primivši projekat ministar

i obavljanje drugih poslova propisanih od državnih vlasti u dogovoru sa crkvenim organima. Saglasno zakonu parohijsko sveštenstvo dobijalo je penziju iz državne kase po zakonu o činovnicima građanskog reda. Sredstva za svešteničke plate i penzije obezbeđivala su se iz ranije uspostavljenog prireza prikupljanog preko Glavne državne blagajne. - Videti: Zakon o parohijskom sveštenstvu, Cetinje, 1909.

${ }^{3}$ Uredba o redukciji i dotaciji parohijskog sveštenstva, o stanju personala manastirkskog sveštenstva, - odeljak A - Redukcija parohijskog sveštenstva, Zbirka uredaba u stvarima Srpske pravoslavne narodno-crkvene autonomije, Novi Sad 1987, 2-3.

${ }^{4}$ Videti; Uredba crkveno-prosvjetne uprave srpskih pravoslavnih eparhija (mitropolija) u Bosni i Hercegovini sa provedbenom naredbom, Mostar 1905.

${ }^{5}$ Videti: D. Novaković, Materijalni položaj episkopata i sveštenstva Srpske pravoslavne crkve od 1804. do 1914. godine, Teme, časopis za društvene nauke Univerziteta u Nišu, 2010/2, 479-506.

${ }^{6}$ „Po ovom projektu, parohijski sveštenik se izdržava: a) od godišnje plate; b) od aktivnog dodatka (doplatka); v) od porodičnog dodatka (doplatka); g) od stana ili srazmerne stanarine, i d) od nagrade za sveštenoradnje i dužnosti koje podležu plaćanju (nabrojane u 
vera zadužio je svoju stručnu službu da prikupi podatke o brojnom stanju sveštenstva, njihovim kvalifikacijama, opštem imovnom stanju crkava i manastira i ukupnom godišnjem prihodu i rashodu. Zbog sporog i neorganizovanog prikupljanja traženih podataka, ministar vera Pavle Marinković odlukom VBr. 9692 od 30. septembra 1920. celokupan posao poverio je licima određenim od Glavnog odbora svešteničkog udruženja koja su u kratkom ruku prikupila dokumentaciju za Srbiju i Makedoniju. Zbog zauzetog stava da smisao Krfske deklaracije i Proklamacije regenta Aleksandra ne dozvoljavaju donošenje parcijalnog zakona kojim bi se uredio materijalni položaj sveštenika Srpske pravoslavne crkve, ministar poljoprivrede i voda dr Velizar Janković, kao zastupnik ministra vera, obrazovao je odlukom VBr. 1131 od 10. februara 1921. stručnu komisiju od osoblja Ministarstva sa zadatkom da prouči celokupno stanje i pripremi propise za unifikaciju materijalnih nagrada za sveštenike svih konfesija. Pravoslavna sekcija završila je rad usvajanjem principa iz kojih je proizlazilo određivanje redovne plate sveštenstvu, koja bi se isplaćivala iz sredstava dobijenih od posebnog razreza na redovni porez, eksploatacije sesija i drugih crkveno-manastirskih dobara, razreza na crkve i manastire i novca prikupljenog od taksi. Prema proračunu iz ta četiri izvora prikupilo bi se godišnje 17.181.836,50 dinara, dok bi za plate svih sveštenika raspoređenih u različite kategorije trebalo isplatiti ukupno 14.992.750,00 dinara. Ocenjujući predlog kao dobar, ministar vera predložio je da se navedena kalkulacija unese $\mathrm{u}$ predlog budžeta i posluži kao osnov za izradu odgovarajućeg zakona, ali ta zamisao nije realizovana. ${ }^{7}$

Uvažavajući složenu religijsku situaciju u novoj državi i neophodnost drugačijeg pristupa $u$ rešavanju problema svešteničkih prihoda, novi ministar vera dr Milivoje Jovanović odlukom VBr. 11.729 od 5. novembra 1921. formirao je stručnu komisiju (anketu) sastavljenu od reprezentativnih predstavnika svih usvojenih i priznatih crkava i verskih zajednica sa zadatkom da dođu do principa za rešavanje najvažnijih pitanja od obostranog interesa, među kojima je u tački 3 bilo i „materijalno obezbeđivanje verskih službenika svih priznatih konfesija“. Dalja aktivnost odvijala se po sekcijama, odnosno konfesijama, i na završnoj sednici cele komisije održanoj 23. novembra 1921, u ime predstavnika pravoslavne crkve usvojen je

čl. 4. čl. 11). Platu dobijaju prema kvalifikacijama, koje se dele u četiri grupe (kako je i kod činovnika predviđeno): A grupa - sveštenici sa fakultetskom spremom: B grupa - matura ili bogoslovija; B grupa - četiri razreda gimnazije ili sprema ravna ovoj, i G) grupa - bez i jednog razreda gimnazije (čl. 2). Plate se odmeravaju i povišavaju prema propisima zak. o platama za državne činovnike i isplaćuju se iz državne kase" - Zakonski projekt o privremenom uređenju materijalnog stanja pravoslavnog parohijskog sveštenstva, Vesnik Srpske crkve, avgust 1922, 15.

${ }^{7}$ Zakonski projekt o privremenom uređenju materijalnog stanja pravoslavnog parohijskog sveštenstva, Vesnik Srpske crkve, avgust 1922, 17-30. 
sledeći stav: „Srpska pravoslavna crkva smatra da je današnji način nagrade pravoslavnog klira nepodesan, a donekle i nedoličan; s toga se ovo stanje mora odmah sanirati. Kliru se mora odrediti sistematska plata, a sa naročitom skalom dodatak izgrađen s obzirom na gora mesta, napornost službe, teritorijalnu veličinu parohije itd. Isto tako mora se obezbediti položaj obolelog, ostarelog sveštenika, kao i penzije porodicama umrlih sveštenika“. ${ }^{8}$ Navedeni predlog o utvrđivanju redovnih plata za sveštenike Srpske pravoslavne crkve nije mogao biti prihvaćen i zbog odbijanja tadašnjeg ministra finansija dr Koste Kumanudija, koji je zastupao stav da se prvo donese poseban zakon o Srpskoj pravoslavnoj crkvi, a zatim rešavaju druga otvorena pitanja.

Poštujući specifičnost njihovog poziva, državni organi su pre donošenja Vidovdanskog ustava preduzeli mere da reše finansijski položaj zaposlenih u eparhijskim crkvenim sudovima. Maja 1920. doneta je uredba, a 8. septembra 1921. i Zakon o platama predsednika, članova, sekretara, pisara i praktikanata eparhijskih duhovnih sudova u opsegu pređ. starih i novih oblasti Kraljevine Srbije. Predsednici i redovni članovi eparhijskih duhovnih sudova, shodno Zakonu o sudijama iz 1911. godine, izjednačeni su u pogledu plata sa sudijama prvostepenih sudova, dok su sekretarima i pisarima prinadležnosti isplaćivane na osnovu Uredbe iz 1913. godine. Praktikanti eparhijskih duhovnih sudova nisu mogli imati godišnju platu veću od 1.200 dinara ni manju od 1.000 dinara. Fakultetska sprema propisana je za predsednika i članove eparhijskih sudova, ali je ta dužnost mogla biti poverena i licima sa bogoslovijama, koja imaju deset godina ukazne službe u crkvenom sudstvu ili na upravno-administrativnim dužnostima. Sekretar suda treba da ima završeni fakultet ili trogodišnje sudsko iskustvo. Plate predviđene Zakonom isplaćivane su i osoblju eparhijskih sudova u Crnoj Gori, Dalmaciji, Bosni i Hercegovini i području Karlovačke mitropolije. ${ }^{9}$

Ocenjujući da pitanje materijalnog obezbeđenja neće biti efikasno rešeno, Glavni odbor svešteničkog udruženja obratio se Svetom arhijerejskom saboru i patrijarhu sa molbom da svojim autoritetom podrže opravda-

${ }^{8}$ Stručna Komisija Ministarstva Vera za rešavanje državno-konfesionalnih problema, Vesnik Srpske crkve, januar, 1922; 82-83.

${ }^{9}$ Zakon o platama predsednika, članova, sekretara, pisara i praktikanata eparhijskih duhovnih sudova u opsegu pređ. starih i novih oblasti Kraljevine Srbije, Vesnik Srpske crkve, januar-februar 1923, 24-27. Uredba iz 1920. godine objavljena je u Službenim novinama, br. 112, maj 1920. Tih godina donet je i Zakon o uređenju naših vojničkih grobalja i grobova u otadžbini i na strani, kao i grobalja izginulih vojnika i mornara, ratnih zarobljenika i interniranih liaca, državljana: Nemačke, Austrije, Ugarske i Bugarske sahranjenih na našoj državnoj teritoriji, Službene novine, br. 27, 22. april 1922, kao i Zakon o regulisanju položaja vojnih sveštenika iz 1922. godine, B. Gardašević, Organizaciono ustrojstvo i zakonodavstvo pravoslavne crkve između dva svetska rata, Srpska pravoslavna crkva 1920-1970, spomenica o 50godišnjici vaspostavljanja Srpske Patrijaršije, Beograd 1971, 53. 
ne zahteve sveštenstva. Uvažavajući molbe, ministar vera dr Ivan Krstelj doneo je 3. februara 1922. odluku o parcijalnom rešavanju problema materijalnog položaja pravoslavnih sveštenika, ali pod uslovom poštovanja principa postavljenih članom 12 Vidovdanskog ustava. Zadužio je načelnika i referenta pravoslavnog odeljenja da dostave detaljan izveštaj o celini problema i pripreme finansijsku konstrukciju, a Udruženje sveštenika da podnese prerađen zakonski projekat. Razmatrajući više puta taj problem, Sveti arhijerejski sinod prihvatio je ranije opredeljenje o isplati svešteničkih plata iz prihoda prikupljenih na način utvrđen u predlogu iz 1921. godine. Izvršavajući nalog ministra, komisija Glavnog odbora udruženja pravoslavnih sveštenika pripremila je i predala 12. marta 1922. Predlog zakona o uređenju materijalnog stanja pravoslavnog sveštenstva u Kraljevini Srba, Hrvata i Slovenaca. Zakon je sadržao 64 člana i detaljno je uredio sve aspekte materijalnog položaja sveštenstva. Predlagači nisu vodili računa o finansijskim mogućnostima jedne nerazvijene države, već su krajnje nerealno utvrđena prava sveštenika ne uzimajući u obzir njihove obaveze. Radilo se u osnovi o nabrajanju spiska želja i nameri da se sveštenstvo kao posebna kategorija izdvoji od ostalog naroda i trajno materijalno obezbedi. ${ }^{10}$

Dostavljeni projekat ministar vera je, pre upućivanje na ozakonjenje, aktom VBr. 3814-922 prosledio Svetom arhijerejskom saboru na proučavanje. Tokom redovnog zasedanja održanog od 12. do 24. juna 1922. u Sremskim Karlovcima, Sveti arhijerejski sabor formirao je odbor arhijereja sa zadatkom da prouči dostavljeni projekat. Posle razmatranja izveštaja, Sabor je pismom Sin. Br. 907 od 1. jula 1922. izvestio ministra vera da je Nacrt razmotren i zauzeto stanovište da predlog Udruženja sveštenika može biti usvojen kao privremeno rešenje, ali samo pod uslovom „da se iz predloga, podnetog od Glavnog Odbora zadrže samo one tačke, koje govore o materijalnom stanju". ${ }^{11}$ Istovremeno dostavljen je i usvojeni Nacrt Zakona o privremenom uređenju materijalnog stanja Pravoslavnog parohijskog sveštenstva u Kraljevini Srba, Hrvata i Slovenaca, koji sadrži ukupno 28 članova. Uvid u navedeni Nacrt jasno pokazuje da je Sveti arhijerejski sabor zastupao stanovište o potrebi celovitog rešavanja materijalnog položaja sveštenika i đakona, ali da je istovremeno ostao u granicama realnosti pravilno procenjujući da složena konfesionalna situacija u zemlji i ukupne materijalne mogućnosti države ne omogućavaju institucionalizovanje privilegovanog položaja sveštenoslužitelja jedne konfesije. ${ }^{12}$

${ }^{10}$ Predlog zakona o uređenju materijalnog stanja pravoslavnog sveštenstva u Kraljevini Srba, Hrvata i Slovenaca, Vesnik Srpske crkve, avgust 1922, 40-55.

${ }^{11}$ Pismo Svetog arhijerejskog sinoda i patrijarha Dimitrija ministru, Vesnik Srpske crkve, avgust 1922, 67.

${ }^{12}$ Nacrt Zakona o privremenom uređenju materijalnog stanja Pravoslavnog parohijskog sveštenstva u Kraljevini Srba, Hrvata i Slovenaca, Vesnik Srpske crkve, avgust 1922, 68-75. 
Tokom narednih godina bilo je više pokušaja zakonskog uređivanja prinadležnosti sveštenstva SPC, ali su državni organi veštim manevrima i pozivanjem na opredeljenje da se prvo donese sistemski zakon o ukupnom položaju te crkve, nastojali da prolongiraju donošenje i obeshrabre Udruženje pravoslavnih sveštenika, koje je kao najzainteresovanija strana, neprekidno podnosilo različite inicijative i preko poslaničkih i drugih grupa vršilo pritisak na izvršnu i zakonodavnu vlast. Kada je postalo izvesno da je u postojećim političkim okolnostima nemoguće doneti poseban zakon, državni organi su odlučili da uvedu određeni red u tu oblast, tako da je 1925. godine usvojena Uredba o dodacima na skupoću sveštenstvu svih Ustavom usvojenih konfesija, a 1926. godine Uredba o nagradama koje pripadaju parohijskom sveštenstvu Pravoslavne crkve za izvršene sveštenoradnje.

\section{Uredba o dodacima na skupoću sveštenstvu svih, Ustavom usvojenih konfesija}

Ne uspevši u nameri da donesu odgovarajući zakon kojim bi se uredile svešteničke plate, a polazeći od ustavne ravnopravnosti usvojenih i priznatih konfesija, državne vlasti su 28. jula 1925. usvojile Uredbu DRBr. 88900 o dodacima na skupoću sveštenstvu svih Ustavom usvojenih konfesija. Navedena Uredba menjana je i dopunjavana 13. marta 1926 (DRBr. 154024), 3. jula 1926 (DRBr. 86255) i 13. maja 1929. Poslednja izmena i dopuna izvršena je posle donošenja Zakona o Srpskoj pravoslavnoj crkvi 20. jula 1930. i zavedena je pod DRBr. 75806. Uredbom je precizirano da aktivni parohijski sveštenici, đakoni i sveštenici u javnim službama, kojima to ministar vera odobri, primaju dodatke na skupoću iz državnih sredstava.

Sveštenstvo i monaštvo u granicama ranije Kraljevine Crne Gore koje dobija platu po Zakonu o činovnicima i ostalim službenicima građanskog reda od 31. jula 1923. primaće lične i porodične dodatke po rešenju Ministarskog saveta DRBr. 42300-24 od 10. aprila 1924. na isti način kao i činovnici. Parohijsko sveštenstvo ostalih konfesija na teritoriji Kraljevine podeljeno je prema mestu službovanja u šest posebnih razreda skupoće. ${ }^{13}$

${ }^{13}$ Prema članu 2 Uredbe, prvi razred obuhvata sveštenstvo svih konfesija u Dalmaciji sa Bokom Kotorskom, gornjokarlovačku i pakračku eparhiju, senjsko-modrušku biskupiju Katoličke crkve i sve grkokatolike u zemlji. Drugi razred obuhvata sveštenstvo svih veroispovesti u Hercegovini (srezovi višegradski, fočanski, rogatički, čajnički i sarajevska oblast), okruzi: beranski, belopoljski, plevaljski, prijepoljski, delove Crne Gore u kojima nije razvrstano po Zakonu o činovnicima i celu Južnu Srbiju. Celokupno sveštenstvo u Srbiji i Bosni pripada trećem razredu skupoće. Pravoslavno sveštenstvo eparhije sremsko-karlovačke, rimokatoličko zagrebačke nadbiskupije i celokupno starokatoličko izvan Srbije i Crne Gore pripada četvrtom razredu. Kompletno sveštenstvo svih konfesija u Sloveniji opredeljeno je u peti razred. Sveštenstvo svih veroispovesti u Hrvatskoj, Sloveniji, Sremu, Bana- 
Zavisno od razreda skupoće utvrđeni su i lični mesečni dodaci po sledećoj osnovi: prvi razred - 750 dinara, drugi - 600, treći - 540, četvrti - 480, peti - 420 i šesti - 200 dinara. Pravo na puni dodatak ima sveštenstvo sa propisanom školom i položenim završnim ispitima, dok nepotpune kvalifikacije podrazumevaju polovinu predviđene sume, uz mogućnost izuzetka po specijalnoj odluci ministra pravde. Pravo na lični i porodični dodatak pripada samo sveštenicima koji služe u propisno sistematizovanim parohijama, župama, džematima i rabinatima sa najmanje 200 domova. Ministar pravde može izuzetno odobriti dodatak na skupoću i sveštenicima koji obavljaju verske obrede za manje od predviđenog broja domova. Pored iskazanog ličnog dodatka, sveštenstvu pripada i porodični dodatak u visini od 150 dinara po članu mesečno. Penzionisani, isluženi i nemoćni sveštenici, kao i kapelani, primaju lične i porodične dodatke $u$ istim iznosima kao aktivno sveštenstvo.

Pravo na lični dodatak imaju i svešteničke udovice, ali su u tom slučaju predviđena tri razreda skupoće. Prvi razred (veliki gradovi) podrazumeva isplatu od 900 dinara, drugi (varoši, slobodni gradovi, sreska mesta) 800 dinara i treći (ostala neobuhvaćena mesta) 700 dinara. Svešteničko siroče bez oba roditelja prima lični dodatak predviđen za udovicu, a kada ih ima više jedno prima ceo lične dodatak, a ostala po 150 dinara mesečno. Pravo na lični i porodični dodatak neće moći da koriste sveštenici ako sopstvenim prihodima mogu da obezbede dostojan život za svoj stalež prema prilikama mesta i vremena. Aktivnom svešteniku biće uskraćeno to pravo ukoliko ima redovne parohijske prihode i imovinu na koju plaća 300 dinara neposrednog poreza godišnje, a penzionisanom, isluženom i nemoćnom kada od imovine ili ličnog rada obezbeđuju mesečno 1.000 dinara. Sveštenicima koji raspolažu manjom imovinom i plaćaju porez od 75 do 300 dinara određuje se prema skali četvrtina, polovina ili tri četvrtine dodatka.

Dodaci na skupoću određuju se aktivnim sveštenicima prema mestu stalnog službovanja, penzionisanim, isluženim i nemoćnim prema poslednjem mestu rada, a udovicama i siročadima prema mestu življenja. Sveštenicima i udovama sa pravom korišćenja ličnog dodatka pripada i porodični dodatak za decu rođenu u braku i pozakonjenu, a sveštenicima i za zakonite žene. Muslimanima sa više žena pripada dodatak na skupoću samo za jednu ženu. Ukoliko je žena aktivni državni službenik, penzioner, sa sopstvenim prihodima od 200 dinara mesečno ili rastavljena, uskraćuje se pravo svešteniku na porodični dodatak. Porodični dodatak ne pripada detetu posle navršene 16. godine života; kada stupi u javnu i privatnu službu sa obezbeđenim prihodima od 200 i više dinara mesečno; bude smešteno u javni, građanski, vojnički, dobrotvorni ili vaspitni zavod na besplatno izdržavanje;

tu, Bačkoj i Baranji, koje nije uključeno po drugom osnovu u neku grupu, pripada šestom razredu skupoće. 
uživa školsku ili naučnu stipendiju od 200 i više dinara mesečno; stupi u trgovinu ili na zanat sa pravom izdržavanja od poslodavca; udomljenjem i ženidbom i ukoliko od sopstvenog imanja može dobiti prihod od najmanje 200 dinara mesečno. Porodični dodatak na dete starije od 16 godina može se priznati kćerki koja vodi domaćinstvo ocu udovcu, ako je telesno i duševno nesposobno za samostalno izdržavanje i u slučaju redovnog školovanja do navršene 23 godine života.

Ukoliko je sveštenikova žena državni činovnik oboje ne mogu primati potpuni dodatak na skupoću već se jedan smanjuje na polovinu. Posebni uslovi predviđeni su za porodični dodatak dece u slučaju razvoda braka ili odvojenog života supružnika. Ukoliko je majka u državnoj službi ili prima penziju, porodični dodatak na decu pripada roditelju kod koga su deca na izdržavanju, dok u suprotnom slučaju muž prima novac i isplaćuje ga ženi ako su deca kod nje. Svešteniku koji u toku godine zbog obavljanja privatnih poslova odsustvuje duže od 40 dana gubi pravo na lični i porodični dodatak. Izbor sveštenika za poslanika i određivanje zastupnika za obavljanje dužnosti, podrazumeva njegovo izjednačavanje u pogledu ovih prava sa sveštenstvom u mestu stanovanja. Boravak u istražnom zatvoru i izdržavanje suspenzije ili kazne povlači uskraćivanje prava na lični i porodični dodatak na skupoću, ali obustava postupka ili oslobađajuća presuda obavezuju nadležne organe da isplate celokupni iznos. Lični dodatak može se uzeti u popis samo u slučaju državnih potraživanja i sudskim putem dosuđenog izdržavanja, dok je porodični nepovrediv.

Zainteresovani za ostvarivanje prava na lični i porodični dodatak na skupoću ispunjavaju poseban formular propisan od ministra vera i polaže jemstvo tri državna činovnika ili sveštenika kao garanciju o istinitosti podataka. Svaka promena stanja treba da bude na vreme prijavljena, a organi koji vrše isplatu imaju pravo da periodično zahtevaju podnošenje novih prijava. Utvrđivanje neistinitosti podataka podrazumeva gubitak svih prava na godinu dana i naplatu nepravilno dodeljene pomoći. Ministar pravde izriče kaznu gubitka prava za sveštenike i njihove udovice, a ministar finansija za jemce. Okružni i gradski protojereji u eparhijama beogradskoj, braničevskoj, šabačkoj, žičkoj, niškoj i timočkoj primaju mesečno po 200 dinara pored ličnih i porodičnih dodataka.

Umesto ranije određenih dodataka na skupoću crkvenim i verskim poglavarima utvrđeni su posebni iznosi novca na ime obavljanja dužnosti. Patrijarh srpski dobijao je 11.000 dinara mesečno, nadbiskup zagrebački 10.000, arhibiskup barski i primas srpski 8.000, mitropoliti Srpske pravoslavne crkve i nadbiskupi beogradski i sarajevski po 8.000 dinara, episkopi SPC i biskupi skopski, križavački, senjski, krčki, splitski, šibenički, hvarski, dubrovački, kotorski, mostarski, banjalučki, mariborski, ljubljanski i staro- 
katolički po 7.000 dinara, vrhovni muftija u Beogradu 8.000, reis ul ulema u Sarajevu 8.000, vrhovni rabin u Beogradu 8.000, vikarni episkopi SPC u Peći i Sremskim Karlovcima, vikarni biskup u Dubrovniku i pomoćni biskup zagrebačke nadbiskupije po 5.500 dinara i apostolski administratori u Velikom Bečkereku i Subotici po 5.400 dinara. Penzionisani episkopi i vikari imaju identična prava kao i aktivni, ali se njihova primanja vode kao dodaci na skupoću. Svešteničke udove i siročad u Dalmaciji, kojima je dodeljena milostinja po rešenju Austro-Ugarske Br. 2872 od 23. decembra 1899, primaće mesečno od 600 do maksimalnih 1.200 dinara. Isti iznosi utvrđeni su rešenjem Ministarskog saveta VBr. 8975 od 23. avgusta 1920. za svešteničke udove i siročad u Južnoj Srbiji koji nemaju pravo na penziju iz svešteničkog udovičkog fonda. Primene uredbe započela je 1. avgusta 1925, a njeno autentično tumačenje davaće ministar pravde u sporazumu sa ministrom finansija. ${ }^{14}$

\section{Uredba o nagradama koje pripadaju parohijskom sveštenstvu Pravoslavne crkve za izvršene sveštenoradnje}

Uredba V. Br. 6793 doneta je 12. maja 1926. na osnovu ovlašćenja proisteklih iz člana 25 Zakona o budžetskim dvanaestinama i člana 98 Finansijskog zakona za 1926-27. godinu i u sporazumu sa Finansijskim odborom Narodne skupštine. Odnosila se na celokupno parohijsko sveštenstvo Pravoslavne crkve u Kraljevini Jugoslaviji, ali su utvrđene tarife iskazane posebno za sledeće oblasti: Srbija i Južna Srbija; bivša Karlovačka mitropolija; Bosna i Hercegovina; Crna Gora i Dalmacija sa Bokom Kotorskom. Kada je u pitanju Srbija i južni krajevi propisane su tarife za 20 najvažnijih verskih obreda, ali su cene nekih bile u direktnoj zavisnosti od visine utvrđenog poreza. Znamenje je koštalo 3,60, krštenje 18, a predbračni ispit 18 dinara. Venčanje je naplaćivano 200, 100 i 54 dinara i bilo je direktno povezano sa porezom kojim je zadužen mladoženja. Neposredni porez više od 50 dinara godišnje podrazumevao je prvu cenu, od 25 do 50 dinara drugu, a ispod 25 dinara - treću cenu. Svečarsko osvećenje vode u kući sa prekadom kolača i koljiva u crkvi plaćano je 10 dinara, a ako se sve obavlja

${ }^{14}$ Uredba DRBr. 88900 od 28. jula 1925. objavljena je u Službenim novinama, br. 178-XXXVIII od 7. avgusta 1925. Izmene DRBr. 154024 od 13. marta 1926. objavljene su u Službenim novinama Br. 64-XVIII od 22. marta 1926. Izmene i dopune DRBr. 86255 od 3. jula 1926. objavljene su u Službenim novinama Br. 166-XLV od 21. jula 1926. Izmene i dopune DRBr. 75806 od 13. maja 1929-I objavljene su u Službenim novinama Br. 147- LXII od 27. juna 1929. Izmene i dopune Br. 3285 od 20. juna 1930-II objavljene su u Službenim novinama Br. 170-LXIV od 29. juna 1930-II. Ovde korišćen tekst Uredba o dodacima na skupoću sveštenstvu svih Ustavom usvojenih konfesija, Crkveno zakonodavstvo Srpske pravoslavne crkve, knjiga druga, Izdavačka knjižarnica Gece Kona, Beograd, 1931, 135-151. 
u crkvi samo 5 dinara. Ukoliko domaćin naročito pozove sveštenika kući da izvrši osvećenje vodice bio je dužan da plati 18 dinara. Mala molitva imala je cenu 18, a velika 27 dinara. Prilikom osvećenja doma svaki sveštenik dobijao je po 50 , a za za jeleosvećenje nad bolesnim čovekom po 36 dinara. Veliko opelo sa vodicom koštalo je 60, 40 i 30 dinara, a malo 30, 20 i 15 dinara i direktno je zavisilo od veličine neposrednog poreza iskazane kod venčanja. Parastos je plaćan svakom svešteniku 18, čitulja na zadušnicama 3, a prekada nad koljivom 5 dinara za ordinirajućeg paroha. Sprovod do groba svaki prisutni sveštenik naplaćivao je po 54 dinara, dok je za čitanje jednog stolpa jevanđelja bilo utvrđeno 50, a za psaltir 40 dinara. Zasebni parastos $\mathrm{u}$ određeno vreme podrazumevao je plaćanje 50 dinara za prisutnog sveštenika. Izvodi iz protokola krštenih, venčanih i umrlih na zahtev privatnih lica naplaćivani su po 15 dinara.

Verski obredi na teritoriji bivše Karlovačke mitropolije za koje je utvrđena cena razvrstani su u 26 grupa. Prilikom pogreba naknadno pozvanom protoprezviteru, pored prevoza, plaća se 30, drugom svešteniku 30 i đakonu 30 dinara. Svečarsko osvećenje vodice kod kuće sa sečenjem kolača u crkvi koštalo je 5 , a ukoliko se sveštenik posebno pozove 10 dinara. Znamenska vodica u kući porodilje imala je cenu od 10 dinara. Svaki sveštenik i đakon dobijali su za parastos sa liturgijom 20 dinara, dok je cena samo sa parastos bila 10 dinara. Spomen mrtvih na grobu po posebnom pozivu koštao je 10, za zadušnice 2 , a za jektenski spomen u crkvi 2 dinara. Prilikom sveštanja masla svakom prisutnom svešteniku pripadalo je po 30 , dok je moleban plaćan 5 dinara. Zainteresovani vernik plaćao je po 10 dinara za čitanje delova iz svakog od četiri jevanđelja. Parusija je koštala 300, a sarandar 150 dinara. Parastos u crkvi sa izlaskom sveštenika na groblje podrazumevao je plaćanje 30, unošenje preminulog u crkvu dodatnih 30, svako zadržavanje pri sprovodu 5 dinara, a čitanje jevanđelja prilikom stajanja 10 dinara. Rezanje kolača domaćin je plaćao 20 dinara. Čitanje velike molitve značilo je izdvajanje 15, a male 10 dinara. Osvećenje nove kuće koštalo je domaćina 40, dok je za oraciju izdvajao 100 dinara. Bračni ispit u kućama mladoženje i mlade imao je cenu 40 dinara, a izostavljanje porodičnog izvešća 50 dinara. Izvode iz protokola rođenih, venčanih i umrlih zainteresovani su plaćali 15 dinara.

Kada je u pitanju Bosna i Hercegovina, verski obredi započeti su znamenjem i molitvom $u$ domu porodilje čija je cena 10 dinara, dok je za krštenje kod kuće trebalo izdvojiti 30 dinara. Molitva bolesniku u crkvi ili parohijskom domu plaćana je 20, a u domu vernika 30 dinara. Osveštavanje koljiva koštalo je 18 dinara u hramu i kod kuće domaćina. Svaki prisutni sveštenik dobijao je za sveštanje masla po 36 dinara. Ukoliko vernik zatraži osvećenje posebne vodice mimo predviđenih termina, bio je dužan da plati 
18 dinara. Sveštanje temelja ili nove kuće plaćano je 36, a istu sumu trebalo je izdvojiti za obred sa solju, semenom ili stadom. Venčanje je koštalo 250, 150 i 80 dinara u zavisnosti od visine neposrednog poreza. Prema istom osnovu plaćano je i veliko opelo 60 i 40 dinara, dok je za malo, nezavisno od poreskih zaduženja, trebalo platiti 30 dinara. Čitanje psaltira ili jedne glave jevanđelja bilo je iskazano sa 20 dinara. Sprovod pri pogrebu plaćan je 50 dinara ako je udaljenost bila do 2 kilometra, dok je vreme od preko pola sata podrazumevalo izdvajanje 80 dinara. Parastos u crkvi ili domu pokojnika plaćao se 15 dinara, a za isti obred sa osvećenjem spomenika trebalo je izdvojiti 60 dinara. Čitulja u crkvi ili na groblju prilikom zadušnica koštala je 3 dinara, kao i spomen jednog imena na proskomidiji ili jektenijama. Pominjanje imena svih članova zadruge ili blagosiljanje hleba koštalo je 5 dinara. Ukoliko pojedinci zahtevaju odgovarajuća prošenija na liturgiji plaćali su 20, a korporacije 40 dinara. Posebno služenje liturgije pojedinac je plaćao 36, a korporacija 180 dinara. Svedočanstvo ili isprava koju je izdavao sveštenik plaćala se 15 , matrikularni izvod 15, a porodični izvod iz domovnika 20 dinara. Bračni ispit koštao je 50 dinara, vodica uz post 10 i bdenije bolesnom ili porodici 50 dinara. Spomen jednog imena jedanput na proskomidiji podrazumevao je plaćanje 1 dinar, sedam puta 10, 40 dana 20,6 meseci 100 i za godinu dana 200 dinara. Večiti spomen na svako ime godišnje plaćan je 30 dinara.

Situacija u Crnoj Gori bila je u određenoj meri drugačija jer su tamošnji sveštenici i u novoj državi nastavili da primaju platu prema zakonima donetim u vreme Kraljevine. Molitva u crkvi plaćana je 3, a u domu 6 dinara. Prilikom jeleosvećenja svakom svešteniku pripadalo je po 10 dinara. Ukoliko se sveštenik naročito poziva vodoosvećenje u crkvi koštalo je 5 , a u domu 10 dinara. Posebno pozvani sveštenici dobijali su za sprovod do groba po 20, dok su za parastos u crkvi svi prisutni sveštenoslužitelji naplaćivali po 10 dinara. Parastosi, naručeni od korporacija, plaćani su svim prisutnim sveštenicima po 20 dinara. Pomen na liturgiji i prekada koljiva koštali su 5 dinara. Zainteresovani za izlazak sveštenika na grob bili su dužni da plate 10 dinara. Čitanje jevanđelja kod umrlih u domu koštalo je 25 dinara. Prisutni sveštenici, osim nadležnog, dobijali su za venčanje po 20 dinara. Izdavanje izvoda iz protokola za privatne potrebe podrazumevalo je plaćanje 5 dinara. Bračni ispit $u$ domu neveste sveštenik je imao pravo da naplati 30 dinara. Blagosiljanje hlebova koštalo je vernika 15 dinara. Ukoliko pojedinac zahteva posebnu liturgiju izvan nedeljnih i prazničnih dana, bio je dužan svešteniku da plati 30 dinara. Salandar s punjem i prosvorom koštao je 200 dinara. Osvećenje novog doma stajalo je 30 dinara, dok su lica koja primaju platu za zakletvu polagala po 5 dinara.

Uredbom je bilo predviđeno plaćanje 22 obreda na teritoriji Dalmacije i u Boki Kotorskoj. Venčanje u crkvi sveštenik je naplaćivao 50, a kod 
kuće 100 dinara. Sprovod domaćina koštao je 80, odraslog člana domaćinstva 40 , a deteta do sedam godina 20 dinara. Ukoliko sprovodu po pozivu prisustvuju i drugi sveštenici dužnost je porodice da im isplati po 30 dinara. Blagosiljanje trpeze o krsnom imenu plaćano je 10, a s birovinom 30 dinara. Molitva kod porodilje u kući koštala je 10 dinara. Domaćin je za jednu liturgiju godišnje bio dužan da plati 50 dinara. Parastos je koštao 50 , godišnji pomen za mrtve 20, čitanje celog jevanđelja prilikom sahrane po svešteniku 30 dinara. Čitanje celog psaltira imalo je utvrđenu cenu od 30 dinara, a moleban Presvetoj Bogorodici koštao je 10 dinara. Bogojavljenska vodica plaćana je 5 , osvećenje vode svake nedelje u godini 100 , a ukoliko se taj obred vrši kući po pozivu 20 dinara. Salander od 42 liturgije koštao je 300, a pola salandara 150 dinara. Parusija je tarifirana sa 600 , a jeleosvećenje 20 dinara. Molitvu porodilji i detetu posle 40 dana trebalo je platiti 10, dok je blagoslov stada, pčela, doma ili nove kuće tarifiran sa 20 dinara. Izvod iz odgovarajućih matrica plaćan je 20 , a svedočanstvo o činjenim oglasima 4 dinara.

Nagrade u naturi koje su sveštenici za obavljene verske obrede primali u pojedinim oblastima ostaju na snazi, osim u Srbiji gde nisu bile ni ustanovljene. Parohijski sveštenici su obavezani da i dalje vrše besplatno sve verske obrede utvrđene važećim propisima. Ukoliko neki pojedinac zahteva obred koji nije predviđen na teritoriji na kojoj živi dužan je da plati maksimalnu sumu iskazanu u Uredbi. Plaćanje verskih obreda povezanih sa visinom neposrednog poreza, vernici koji žive u proširenim domaćinstvima, izmirivaće obavezu predviđenu za zadruge. Ukoliko dođe do povećanja neposrednog poreza, verski obredi vezani za njih uvećaće se u istom procentu. Ministar pravde dužan je da daje potrebna objašnjenja u vezi sa izvršavanjem Uredbe, dok su dopune moguće u sporazumu sa Finansijskim odborom Narodne skupštine. Predviđeno je da uredba stupi na snagu 1. januara 1926. posle čega prestaje važnost svih propisa na osnovu kojih su pravoslavni sveštenici naplaćivali usluge. ${ }^{15}$

Suočeni sa novom realnošću, teško prihvatajući gubljenje stečenog privilegovanog položaja u Srbiji i Crnoj Gori i sa svešću da pripadaju pobedničkom narodu na čijoj žrtvi je stvorena nova država, episkopat i sveštenstvo jasno su istupili sa stavom da je neophodno trajno rešiti težak materijalni položaj sveštenoslužitelja Srpske pravoslavne crkve. Koristeći početna nesnalaženja nove vlasti i još uvek nedovoljno profilisan stav političkih sna-

${ }^{15}$ Uredba V. Br. 6793. od 13. maja, 1926. god o nagradama, koje pripadaju parohijskom sveštenstvu Pravoslavne crkve za izvršene sveštenoradnje, Službene novine, br. 129. XXXIV, 9. jun 1926. Ovde korišćen tekst objavljen u Crkveno zakonodavstvo Srpske pravoslavne crkve, knjiga druga, Beograd 1931, 109-118. 
ga sa zapada države, istupilo se sa zahtevom za donošenje zakona kojim bi se sistemski rešilo to pitanje. Urađeno je više zakonskih tekstova, ali je njihovo usvajanje prolongirano zbog jasnog političkog opredeljenja o ravnopravnosti usvojenih i priznatih crkava i verskih zajednica iz koga je proizlazila nemogućnost parcijalnog rešavanja položaja sveštenika samo jedne konfesije. Postepeno je zaoštravana i retorika između Sabora i Sinoda kao crkvenih vlasti i snažnog Udruženja sveštenika, koje je uz pomoć lobista iz različitih političkih struktura nastojalo da rešavanje egzistencijalnih problema sveštenstva iskoristi kao priliku za uspostavljanje privilegovanog statusa. Dolazak do rešenja ometali su i sve izraženiji kanonsko-pravni problemi u čijem središtu je bila rasprava o mogućnosti donošenja posebnog zakona o Srpskoj pravoslavnoj crkvi i ostalim konfesijama u Kraljevini.

Političke strukture na vlasti pravilno su procenile da su različitim međunarodnim i domaćim dokumentima preuzete obaveze i rešenja ugrađena u Vidovdanski ustav utvrdila ravnopravnost priznatih i usvojenih konfesija, smanjili manevarski prostor i praktično onemogućili parcijalno rešavanje problema jedne crkve ili verske zajednice. Pažljivo prateći situaciju i polazeći od realne procene da sveštenstvo teško obezbeđuje sredstva za normalan život, Vlada je usvojila uredbu o dodacima na skupoću, kojom su obuhvaćeni sveštenoslužitelji svih Ustavom dozvoljenih konfesija. Prema mestu službovanja određeno je šest razreda skupoće, a kroz lične i druge dodatke obezbeđena je minimalna socijalna sigurnost sveštenika, verskih službenika, penzionera, udovica i dece.

Uspevši da Uredbom o dodacima na skupoću u velikoj meri smanji pritiske, država je postepeno preuzela inicijativu. Umesto očekivanog zakona, sa velikom odlučnošću i bez čvrstog uporišta u pravnom poretku, donosi se uredba kojom se težište problema sa rešavanja materijalnog statusa prebacuje na zaštitu vernika od neumerenih zahteva sveštenstva prilikom naplate verskih obreda. Surovom pravničkom logikom i bez uvažavanja činjenice da je uz velike napore postignuto crkveno jedinstvo uspostavljanjem Patrijaršije, državna teritorija deli se na četiri oblasti u kojima je za precizno navedene verske obrede određena i tarifa. Analiza pokazuje da se radilo o istim ili sličnim obredima i da je visina plaćanja zavisila od ekonomske snage oblasti za koju su propisani.

Izneti primeri rešavanja materijalnog statusa sveštenika Srpske pravoslavne crkve jasno pokazuju da su prve godine obeležene i neprilagođenošću episkopata i sveštenstva novoj društvenoj stvarnosti, teorijskim dilemama i žestokim polemikama stručnjaka oko ustavne pozicije Crkve i njenog novog odnosa sa državom. Omeđena ustavnim odredbama i koristeći poziciju jače pregovaračke strane, država je neprekidno tražila rešenja koja su trebalo da omoguće zadržavanje kontrole nad Crkvom i ispune očekiva- 
nja episkopata i sveštenstva da kompletnu organizaciju i sve segmente crkvenog života usklade sa pravoslavnim kanonima. Kao krajnji rezultat dobijana su kompromisna rešenja iz kojih proizlazi želja države za uspostavljanjem ili zadržavanjem dominacije, ali i nespremnost episkopata da se $u$ promenjenim okolnostima previše udalje od države od koje je očekivana pomoć za rešavanje različitih organizacionih i egzistencijalnih problema.

Dragan Novaković

\section{RESOLVING THE FINANCIAL POSITION OF THE SERBIAN ORTHODOX CHURCH CLERGY IN THE KINGDOM OF SCS-YUGOSLAVIA BEFORE THE ADOPTION OF THE CHURCH CONSTITUTION IN 1931}

\section{Summary}

Complex and important issue of resolving the financial position of the Serbian Orthodox Church clergy in the new state has been presented. Starting with the great sacrifices endured during the war and the credit for contribution to the goals of the Serbian leadership, the Episcopate and clergy unanimously came forward with a request for solving the issue by adoption of an appropriate law. A number of texts had been submitted, but they were not adopted because of the political stance of necessity of compliance with the earlier reached agreements and constitutional provisions of equality of the recognized and adopted confessions. Recognizing the difficult financial position of clergy and adhering to the commitment that the adopted standards apply to all, the Regulation on the additions to the high cost was adopted, which provided basic social security to all the priests and religious officials. Precisely determining the awards for Orthodox priests for performed religious ceremonies, the state sent, through the new regulation, a clear message that it did not intend to give up control of the Serbian Orthodox Church and that it would apply the standards and procedures that were not designed for other confessions. 